\title{
ESSAYS
}

\section{Adi Wimmer}

\section{"Don't Forget About Electra!" Elizabeth Jolley's Life and its Reflection in her Works}

H. Lawrence $(1923,25)$ coined one of the most often quoted
critical maxims of the $20^{\text {th }}$ Century: "Never trust the author. Trust the tale. The proper function of a critic is to save the tale from the artist who created it." Was his stern command heeded? Not at all times and not by all critics. But with the rise of literary postmodernism Roland Barthes' credo of the "death of the author" substantially refreshed Lawrence's maxim. Jacques Derrida (1967) famously added that there was nothing outside the text: "Il n'y a pas de hors-texte." I am aware that the quote contains a pun and I am also aware of the dangers of literality here, but Derrida was widely accepted as claiming that literary art had no points of contact with the real world, which of course included the author. The Postmoderns go one step further. Not only do they not trust the author, they don't trust anyone.

Elizabeth Jolley, whose death in February 2007 we mourn, provides a case for picking up D.H. Lawrence's gauntlet. Some of her novels are brilliantly innovative in her treatment of human character, which led some critics to describe her as archetypally postmodern in her artificiality and unreliability. Rod Moran (2007) praised her art as possessing "irony, pathos, wit and, at times, a sense of the absurd". And yet she herself stated that all her writing came from life, her own and those of her family members. This is immediately apparent in a trilogy of semi-autobiographical novels. Peter Craven (2007) emphasized her autobiographical slant when he argued she had created "a wholly different form of autobiographical fiction" that was "classical in expression and luminous in its minimalism". Her art would be hard to understand 
without knowing her life, particularly her troubled relationship with her mother. In this paper I will explore precisely this relationship and a fictional trope: The Teeth Mother.

I met Elizabeth Jolley only once, in March 1989. She offered me tea in the kitchen of her Claremont house. How do you feel about your literary fame coming to you so late in your life, I asked. Her response was a grim "I can hack it." From that meeting till June 2002 we maintained a lively correspondence. Why with me? I think she liked to have a link to Austria, a country that might have been her home, and to which she was connected both through her command of German and her love of music. The biological connection was through her mother Margarete (or Grete) Fehr. In 1919, English Quakers operated a number of soup kitchens in poverty-stricken German cities; Vienna was their only Austrian location. Jolley's father Wilfred Knight went to Vienna as a volunteer helper and there fell in love with Margarete. She accepted his proposal, hoping to escape the depression and poverty of post-war Vienna.

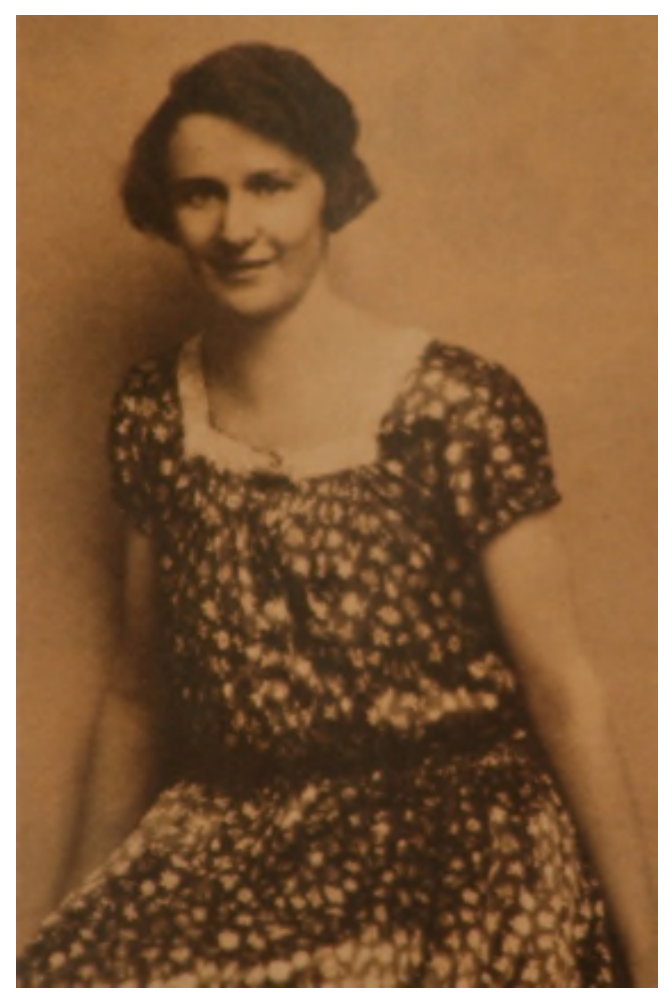

In her essay collection Central Mischief (1992) Jolley devotes a whole chapter to her mother Grete's adulterous relationship, grudgingly tolerated by her husband, with the generous Mr Berrington. Grete Fehr had hoped for a life of comfort and culture with her English husband, but soon she found out that her husband's meagre salary as a maths teacher in a grimy English Midlands city did not allow for luxury. Viennese life may have been short of food, but it was rich in culture. The marriage was in trouble. But not just the marriage: her relation to daughter Elizabeth seems to have been characterized by domineering and scowling. In 2001 Jolley wrote 
how her mother "absolutely wrecked" a Christmas Evening because of a minor act of disobedience, that of running a bath and washing the hospital smells out of her hair without asking permission.

I came home are-verning afterbenig on duty from seven a.m. Till five thinty p.m I was workery in out Patients, there were war time conditions and very few buses and tramis. when I did get hame finally she screamed at me for washing my hairs, it was christimes Eve I had rumied her evenis by being stupid enaph to warh my hair in such a selfich way

In 1930 Grete formed a relationship with a student of hers in a German evening course that she instructed.

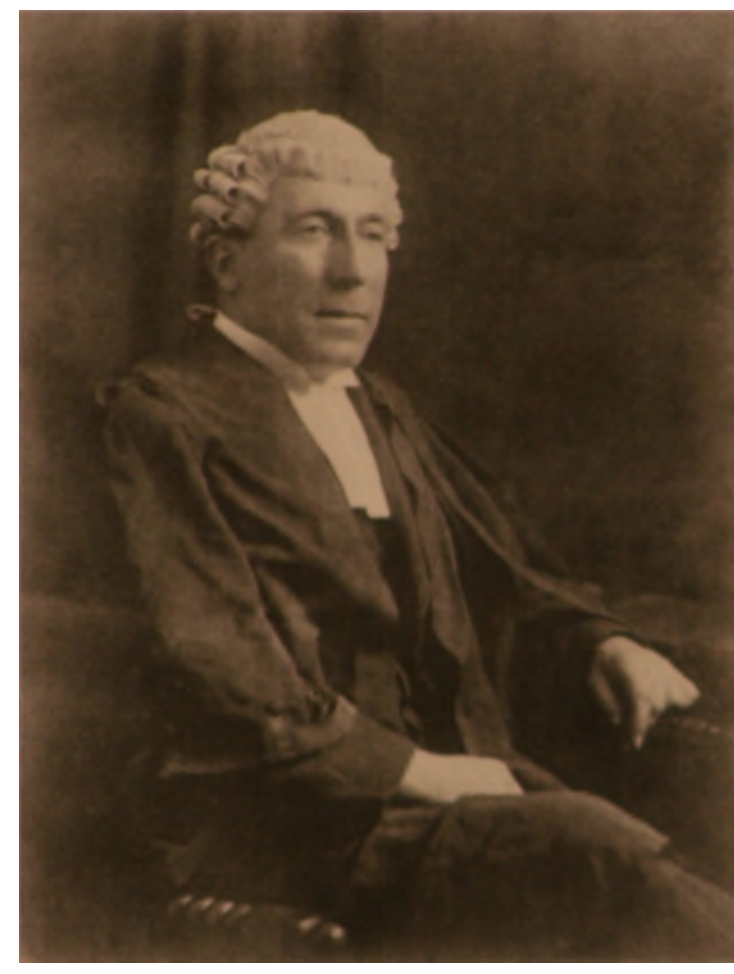

He was Mr Berrington (not his real name), the son of a former mayor of Wolverham-pton, an Oxford law graduate and wellplaced Civil Clerk with considerable private means. (Dibble 29-30). Some 20 years older than Grete he was still single. Berrington, not untypical for the times, was a Germanophile pacifist and asked Grete to provide private language tuition. Grete's tuition soon included other things beside irregular German verbs. Jolley's comment on the situation is plain: "Both Mr Berrington and my father loved my mother" $(1991,114$.$) More outspoken is her$ comment on that curious ménage a trois in an earlier interview: 
There were the most awful family rows, with total lack of understanding. I understand it now, but at the time I couldn't. My mother had a 'Friend', a lover if you like, that my father tolerated. Both men would go to their respective church services on Sunday and then come back home to a dinner cooked by my mother. Then my mother would go with her 'Friend' for the rest of Sunday. (...) Then she would come back at night. My father would get very restless and prowl about the house (Headon 41).

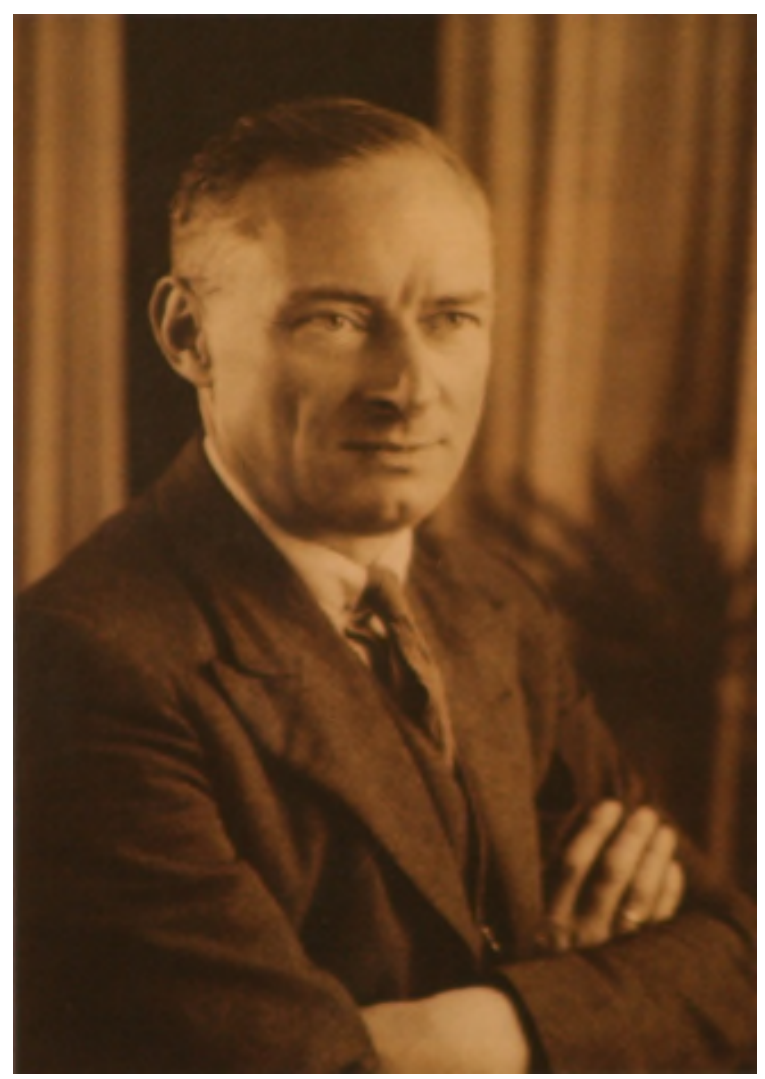

In 1938 Berrington ("he was the real lover, he brought presents and chocolates and clothes") paid for a two-week trip to southern Germany for Grete and her daughters Elizabeth and Madeleine, while Wilfred Knight stayed behind. Berrington also paid for Madeleine's school fees (Elizabeth's younger sister) at the Quaker boarding school of Sibford.

Wilfred Knight, pictured below, grudgingly accepted this ménage a trois. He was a life-long pacifist.

He even accepted it when once he caught his wife in flagranti delicto; she had faked a near-nervous breakdown demanding from him a break from her household chores to enjoy concerts and plays in London. Alone, of course. Wilfred, to please his daughters, suggested a camping trip in the Pennines during her absence. But it began to rain and the girls were less than happy with their father. To lessen their unhappiness, he told them of a hotel to which they could hike, there to dry themselves and have a cooked breakfast. When they walked into the lobby the first person they saw was Grete, and immediately behind her, Mr Berrington - "in impeccable white flannels". The men shook hands and started a conversation - as if their meeting had been a normal occurrence. 
This astonishing detail was revealed by Jolley three years after her description of her mother's fling in a "Summer reading" article published in The Age (1995). Grete carried on the affair until Berrington's death in 1953; he left her $£$ 27.000, which, allowing for inflation, would now be the equivalent of $A \$ 1$ mio. (Dibble 32).

"I do not maintain", writes Jolley in her ominously-titled essay "What Sins to Me Unknown Dipped Me in Ink?", "that a writer should conceal her private life" (6). It is a key sentence about Jolley's early family situation. That ink is Hamlet's "inky cloak", the trauma of a mother's adultery, which was given the name of 'Elektrakomplex' by Sigmund Freud. In Foxybaby Miss Peycroft advises the novelist Miss Porch: "and for heaven's sake don't lose sight of the Oedipus and Electra complexes" $(1985,124)$. Another central character (in An Accommodating Spouse) who is only described as "The Professor of Literature" directs his students to discover

the human element in the ancient myths ... an example being the Electra of Euripides (...) more particularly, the powerful dialogue between Electra and her mother, words of painful truth, which still exist between mothers and daughters at the present time (196).

And in Jolley's final novel An Innocent Gentleman (2001) there is a short treatise on Elektra and Orestes and Jason (171-2). Summing up: The significance of the Electra story is undeniable. As is the significance of her mother's betrayal. For Brian Dibble, Jolley's biographer, that betrayal became "the central drama of her life" (2008, 253).

Who was Electra? She is one of the best-known heroines of all Greek mythology; all three ancient Greek playwrights, Aeschylus, Sophocles and Euripides dealt with the so-called Oresteia in plays. Agamemnon and Clytemnestra had a son and a daughter, Orestes and Elektra. When Agamemnon, after an absence of ten years, returned to his wife from the Trojan War, he was murdered by his wife and Aegisthus, who had become her lover. Electra urged 
Orestes to revenge their father. Together they carried out the deed, killing both Clytemnestra and her lover. The so-called "Electra complex" is the female equivalent of the Oedipus complex in Freudian psychology.

In his biography of Elizabeth Jolley Doing Life (2008), Brian Dibble writes that by the age of only twenty-six Jolley had found the literary topics that would "occupy her for the rest of her life", namely "the home and the family" (96). And we all know that at the centre of both we have the mother figure. So let us investigate the core of Jolley's narratives, and that is the mother-child relationship - more specifically, the mother-daughter relationship, which according to most family psychologists is the most difficult amongst all family relationships. First, how did Jolley herself fare in this respect? In a nutshell, badly. She resented her mother because her German-speaking background and her insistence that her daughters speak German made her an outsider in the street they lived. When the affair with $\mathrm{Mr}$ Berrington started, that resentment deepened. She also came to idolize her cuckolded father; an Electra complex may have been in the making already in her teenage years. In an ABC interview of 1991 Jolley says, with a forced smile, "my mother wanted a princess but what she got was me." She also published a curiously coded essay with the Freudian title of "Good Knight, my Prince" (Central Mischief 125131). Grete Knight did not respect Elizabeth's work; she viewed the profession of a nurse as a menial job; there were many quarrels about it. And yet she insisted that Elizabeth return to the family whenever her hospital work allowed it - so that she could harangue her. When Elizabeth aged 23 had to admit of her pregnancy by Leonard Jolley, whom she was to marry seven years later, Grete Knight heartily disapproved of her daughter and liked to remind her that she was "a fallen woman" as well as "a bad mother" (Dibble 108). Shortly before Elizabeth, Leonard and their three offspring emigrated to Perth in 1959, her son Richard (aged 7) wanted to know whether his English granny would be there too. "Only if she flies by broomstick" was Elizabeth's response (Dibble 136). 
Now for some textual analysis: Her short story "Paper Children" (Woman in a Lampshade, 1983) is a narrative whose main character is a Viennese lady doctor whose name is Clara Margarete Carolina Schultz; Jolley's mother's name was Margarete Johanna Karolina Fehr. Margarete's ambition for her daughter Elizabeth had always been she should become a doctor. Another parallel is that Clara is described as "the daughter of a baroness"; Margarete Knight had made the same (false) claim about herself to her husband and her children (that her father had been a baron and a General in the Austrian imperial army). ${ }^{1}$ The fictional Clara Margarete Carolina Schultz was married to a Jew and had a daughter by him. The fictional time is 1938 , the year that Austria was annexed by the Nazis. Because of that and a lack of wifely support her husband suicides. The threat of a persecution of Jewish children looming, but also because she really only cares about medical science and not her daughter, Clara arranges for her infant daughter, Lisa, to be sent to Australia. And now, 25 years later, in which time she strangely never tried to be reunited, infirm and in retirement, she prepares to visit her in Australia. Observation No. 1: here we have a Viennese mother accused of betraying her husband, and as a result he kills himself. She has the same Christian names as Jolley's mother (Margarete and Karolina) and a daughter living in Australia named Lisa (i.e. Elisabeth). Lisa is the Australian version of Lieserl, the nickname that Elizabeth was given by her parents and her Viennese relatives. Naturally she (Lisa) lives in dread of the mother's visit. The resolution however is: Clara Margarete Carolina dies in her Viennese apartment. When Lisa goes to meet her mother at the Sydney airport, she is instead met by Irma Rosen, her mother's next-door neighbour. The Australian Lisa will now have to fly back

1 Jolley repeated that claim at least twice in early autobiographical writings. In her short story "One Christmas Knitting" the female narrator similarly says: "Like my mother, Aunti Mote was a baroness in her own right" (Woman in a Lampshade, 123). Brian Dibble was able to prove that Margarete Fehr's father was only a humble station master with the Austrian Imperial Railways. 
to Vienna to settle her mother's estate. Elsewhere I have argued that for Jolley, Vienna was a 'primal scene', the locus of her parents' first love-making, and thus a site which she should have claimed as a heritage (Wimmer 1992).

Thus the first example for a narrative in which Jolley symbolically kills her mother.

There is a passage in "Mr Berrington" in which Jolley writes that her mother had the uncanny ability to make everyone around herself unhappy. Her dark and uncomfortable novel Milk and Honey (1985) would be an example for a treatment of this her mother's quality. Let us proceed to that novel.

The story is of the Heimbach family, once again Viennese refugees of Nazi persecution. It is a degenerate family whose head Leopold, a musician and cello instructor, traps young Jacob, a gifted cellist, into marrying his daughter Louise so that he is forever tied to the family. But here comes the most intriguing detail. Jacob responds by starting an affair with an older woman named Madge, short for Margaret/e. So the ménage a trois that we find in the triangle Margarete - Mr Berrington - Wilfred Knight, and later in Elizabeth - Leonard Jolley - Joyce Jolley, is replicated in this story. At the end of the novel the imbecile Waldemar murders Madge/Margarete, who was unfaithful to her husband Norm (like Margarete Knight was unfaithful to her husband Wilfred.) The narrative presents the second example of a symbolic matricide.

There is another angle to this family tragedy and it lies in Leopold's wife Heloise. After Leopold, who was not himself Jewish, emigrates to Australia with his wife and two sisters, just so that Heloise does not fall into the hands of Nazi race laws, Heloise has to be committed to a mental hospital. She is not capable of adjusting to the culture she encounters, a clear echo of Margarete Knight's dissatisfaction with Wolverhampton after she had been raised in Vienna. So she fails her husband and her children as well as her two aunts, and Leopold is forced to embark on a very 
unethical course of action which results in several deaths, including his own. It is not a very flattering picture of a Viennese mother whose cultured upbringing is of no use in a new Australian setting.

But the clearest case where Jolley, acting upon the Electra complex, symbolically murders her mother occurs in the short story "Two Men Running."

The narrator and his mate are long-distance runners. His mate calls him 'Hamish' although Hamish protests that this isn't his name. Hamish is locked up in jail and once a week he is seen by a psychiatrist. The Psychiatrist wants him to tell "what happened", but Hamish does not cooperate. The psychiatrist keeps telling him his "memory will come back." As Hamish and his mate are running he offers the information that he was a salesman in the morning, an abortionist in the afternoon and a poet in the evening. Later in the same passage he calls his friend "Hamish", i.e. by the same name that he was earlier called. We realize that the narrator and his running partner are one and the same person. He has a split personality and that is why he has psychiatric therapy aimed at the recovery of his memories. And there is a snatch from a song he sings: "One day the man I used to be / will come along and talk to me" (51).

When Hamish conducts his interior monologue he does have memories. Little by little we learn that he was once very close to his father, George Enderby. George was a travelling salesman, and he had a partner called Marge (!) Parks, who owned and operated a farm. Hamish and his father would be out in rural Australia selling merchandise to remote communities, but they would always return to the safety of Marge. Who, it seems, has made an offer to George: whenever he decides to quit his travelling business he can settle down with her on the farm.

There is a prefiguration of what is to happen in the description of a cockfight that Hamish observed on the farm. A strong cockerel, the established king of all the farmyard hens, is challenged by a younger cockerel. The fight is fierce and brutal. Gradually the second cock wins the upper hand. The older cock loses blood and becomes limp. (My Freudian spin on this detail is unavoidable.) 
George throws a bucket of water over the two to separate them. The older cock seems in despair: "It was as if he knew the end of his life had come and he sank down nearer the ground. He refused food and water and stood there sad and ashamed and we didn't know what to do for him" (55).

After years of travelling, George Enderby decides he will quit. In the opening passage, Hamish suddenly remembers a Country ' $n$ Western song and sings two lines: "country road, take me home/ to the place/ I belong". All will be well if he drives home to Marge, taking up her offer of permanent residence. But when they get there, Marge is curiously distant. There is no warmth in her and no invitation to stay:

Her long cold stare fixed just beyond him made me shiver. "There's no need to come up to the house" she said. "There's the tap down by the bottom shed" she said, you can use that".

He couldn't believe it. He stared at her.

"My energy's gone Marge."

"I can see that George."

"No need to come to the house, Marge, is that what you're saying Marge?"

"It is George."

"No need to come to the house Marge after I've been coming all these years and we've always said ..."

"Dad" I said to him, "Dad, don't! Don't go on." (59)

Soon the reason for her change of heart becomes apparent, and he is called Franz Heiss. Heiss means 'hot' in German, a language with which Jolley grew up. It also allows associations with the names of two Nazis: One is Rudolf Franz Höss, the commander of Auschwitz /Oswiecim, the other is Rudolf Hess, Hitler's deputy until 1941. Jolley made references to Nazis in other stories; in "Paper Children" she uses the term 'Gauleiter' for a particularly brutal male. And we know from Dibble's biography that up to 1939, her mother was all for Hitler. In the summer of 1938 when Berrington and his mistress toured Germany, Elizabeth Knight aged 15 participated in a youth camp organized on behalf of the Bund deutscher Mädel. 
Later, when they pick up the game again Hamish says to his father: "I've got a sick horse." His dad's reply comes after a pause: "Sick or just old"? And Hamish: "A bit of both", and "it was then that I burst out crying" (63).

The metaphor is extended again two pages later when Hamish tells his father he has a new gelding amongst his toys. This is clearly a reference to Franz Heiss, the new arrival. The father retorts: "that's no gelding my boy, I'd say he was a fine stallion, a fine stallion." Handing back the toy horse he also hands to his son a brass screw. We can only read this as the father's acknowledgement that Franz Heiss is now screwing Marge.

The horrible climax of this story comes when Hamish tells his alter ego what it was that brought him into prison. Years later and now an adult he drove to the farm, arriving in the evening, where he was greeted by a rather nervous sounding Marge. He forced her into the bedroom and raped her. When he has perpetrated the deed Marge tells him, to his horror, that she is his mother. For reasons that we can only guess at she did not acknowledge motherhood to the world. Without knowing it, Hamish has committed the archetypal Oedipal crime of sex with his mother. You will recall what Oedipus' response was: he blinded himself so that he would not have to look at the crime. Hamish' reaction is similar. "Not the knife" screams Marge, but to no avail. He has to kill the only 'eye-witness' to his crime.

Why does the story have such a hard edge to it? We are allowed to develop sympathy with Hamish, the killer, but there is hardly any sympathy for his victim Marge. When we meet Hamish he is in "a gallery". There is a double meaning to that: it can be a place in a high security prison, but it is also a place where paintings, portraits maybe, are displayed. So Hamish gets a chance to present a self-portrait. How he does that establishes a clearly discernible woman-hating subtext. It is introduced with the term "abortionist", the term for a profession that has desperate women 
as customers. The story includes a quote from Shakespeare's King Lear, which continues the misogynous discourse:

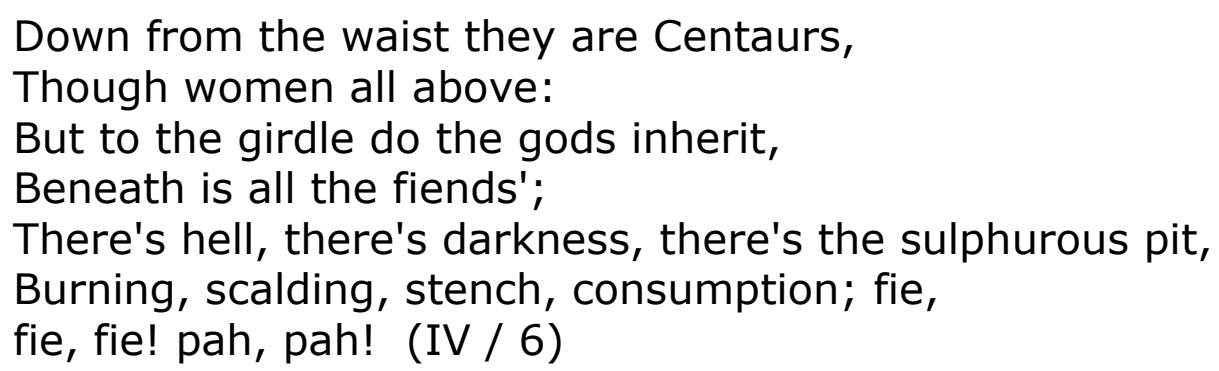

What emerges is the overturning of the traditional notion that mothers are cherishers and nurturers. Here we have the Teeth Mother exposed. Marge is a deceitful and lecherous woman, one in whom sexual lust has priority over fidelity. The biographical reasons why Jolley came up with this portrait are patently clear: the Madge of this story is yet another variant of Margarete, the adulterous mother.

Some critics have read Jolley's novels in terms of characters searching for a lost mother. Coral Ann Howells for instance reads the novel Miss Peabody's Inheritance as Jolley's attempt "to write [her] way out of dispossession into inheritance" $(1988,55)$. That Jolley did not feel at home in her new Australian environment for many years is well documented; her protagonist Miss Peabody on the other hand is unhappily tied up in England, forced to nurse a domineering mother. With her epistolary friendship to author Diana Hopewell she enters into a new phase of her life and finally escapes the clutches of her mother when she, like Jolley, emigrates to Australia. For Howells, "women's sense of not belonging in the place where they live and their eventual coming into inheritance by adoption" (58) constitutes a post-colonial paradigm. What Howells does not take into account is that Jolley escaped from an inheritance. That she suffered emotionally from that escape is also apparent. When Peabody takes over "the persona and voice of her lost mother in another country" (60) this is a symbolic inversion of a mother's attempt to force her own voice and identity onto a daughter. Joan Kirkby argues that right 
from her beginnings, Jolley was engaged in the discourse of writing 'the feminine' or 'woman' as problematic. The "paternal fiction" being "in decline", writers like her have endeavoured to make the mother ("excluded from the symbolic order") into the major preoccupation of her art. Kirkby goes on to argue - rightly that all her novels contain aspects of a "damaging Oedipal scenario". And so her characters are all "father-identified" and have "rejected the maternal". That rejection "impels them at time to a violent rejection of other women, the murder or sacrifice of another who is in reality the self" $(1988,46-47)$. Kirkby is right to present characters such as Laura (in Palomino) or Leila (in The Sugar Mother) as "father-identified"; moreover, Miss Porch's novel (in Foxybaby) is clearly an incest narrative. The tragedy, ends Kirkby, is that these mother-searching characters are unable to "escape the crippling legacies of the symbolic order" (54). Helen Garner, one of the earliest to appreciate the feminist discourses in Jolley, is less harsh in her judgement. Yes, she admits, her women are usually to be found in "grim" situations. They are "struggling against hostile circumstances ... and some of them are right over the edge, ill with homesickness, helpless, deregistered, blackmailed." All the same "they are battlers" ... they keep going" (Garner 157).

In 1979 Jolley's mother died. As the years progressed Jolley came to a revision of her hostile attitude; according to Dibble the volta came with her novel The Orchard Thieves (1995). This is not the place to detail how reconciliation came about. Suffice it to say for the moment that in her last two novels triangular relationships are treated in a sympathetic way, with lots of sympathy and understanding for the desires that are involved. In her last novel An Innocent Gentleman (2001) the previous moral perspective is overturned: Muriel Bell, married to the teacher Henry Bell and with two daughters (!), enters into a relationship with 'Mr Hawthorne.' The time is 1941 and the Blitz is on in London; all the same Hawthorne invites Muriel to spend a weekend in London with him on the pretext that he has two tickets for Fidelio, Beethoven's famous opera on the theme of liberation from the chains of 
bondage. While in London, there is an air raid, and the hammering that the Luftwaffe gives the city only enhances their passionate love-making described with delicacy and sympathy (188-9). After Muriel becomes pregnant the cuckolded husband, in an all-too understandable revenge action, allows himself some hanky-panky with his next-door neighbour Mrs Tonks. The scene is described in a revolting manner, a far cry from the romantically described tryst between Muriel and Hawthorne. Did Elizabeth Jolley symbolically 'make up' with her mother whom she had depicted in less than flattering terms? The novel ends on hopeful note with Bell and Hawthorne sharing Muriel as sexual partner (as Jolley's father shared his wife Grete with Mr Berrington) and the responsibilities of raising their little baby boy.

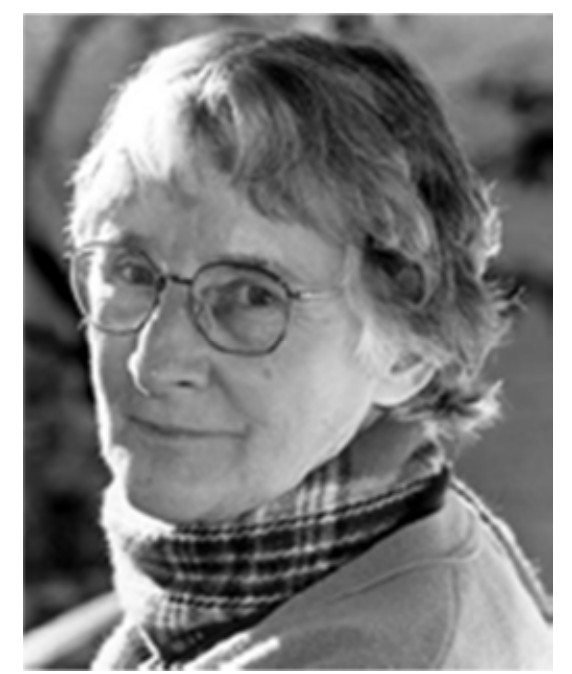

All good writing must come from experience and truth, was Jolley's often heard motto. Her life-long treatment of her own "Electra experience" and her resentment of the treatment she had by her mother, a resentment which gradually gave way to understanding and then even sympathy, has given us a number of fascinating treatments of that inexhaustible subject, erotic desire and the confines of marriage. It seems clear to me that in this author, it is impossible to separate the tale from the teller.

\section{Works Cited:}

Anon, ed., 1991. "Elizabeth Jolley", Contemporary Authors Autobiography Series, Vol. 13, 105-123.

Barthes, Roland, 2008 [1968]. "The Death of the Author". In:

The Routledge Critical and Cultural Theory Reader. London: Routledge, 2008, 121-125.

Craven, Peter, 2007. "Black Humor, Jolley Heart". The Age, 27

February 2007 (Obituary).

Derrida, Jacques, 1967. De la grammatologie. Paris: Éditions de 
Minuit, 158-9.

Dibble, Brian, 2008. Doing Life. A Biography of Elizabeth Jolley.

Crawley, WA: UWA Press.

Garner, Helen, 1983. "Elizabeth Jolley: An Appreciation", Meanjin

42:2, 153-157.

Headon, David, 1985. Interview with Elizabeth Jolley. Meanjin 44:1, 39-46.

Howells, Coral Ann, 1988. In Search of Lost Mothers: Margaret Lawrence's "The Diviners" and Elizabeth Jolley's "Miss Peabody's Inheritance." Ariel, A Review of International English Literature 19:1 (January), 56-70.

Jolley, Elizabeth, 1983. Woman in a Lampshade. Ringwood, VIC: Viking.

--.-- , 1983. Miss Peabody's Inheritance. St Lucia: University of Queensland Press.

--.-- , "Two Men Running". In Woman in a Lampshade, 47-70.

--.-- , 1985. Foxybaby. St Lucia: University of Queensland Press.

--.-- , 1992. Central Mischief. Elizabeth Jolley on Writing, her Past and Herself. Ringwood VIC: Viking.

--.-- "Mr Berrington". In Central Mischief, 31-38.

--.-- "What Sins Unknown Dipped Me in Ink?" In Central Mischief, $1-12$.

--.--, 1995. "Summer Memories: Outlines and Shadings." The Age, 6 January, 7.

--.-- , 1999. An Accommodating Spouse. Ringwood, VIC: Penguin.

--.-- , 2001. An Innocent Gentleman. Ringwood, VIC: Penguin.

Kirkby, Joan, 1988. "The Call of the Mother in the Fiction of Elizabeth Jolley." Journal of the South Pacific Association for Commonwealth Literature and Language Studies, April, 46-63.

Lawrence, D.H., 1923. Studies in Classic American Literature. New York: Seltzer.

Moran, Rod, 2007. "Writer Elizabeth Jolley Dead". Sydney Morning Herald, 27 February.

Wimmer, Adi, 1992. "Dualism and the Austrian Connection in Elizabeth Jolley's Fiction." Southerly (Sydney: The English Association: Sydney Branch) 52:2, 44-55. 